\title{
DIGITIZATION PRACTICES AT LITHUANIAN MUSEUMS AFTER THE LIMIS IMPLEMENTATION (2008-2017)
}

\section{AYA KIMURA}

\section{ABSTRACT/ABSTRAKT:}

This study focuses on LIMIS (Lithuanian Integral Museum Information System) and Lithuanian public museums, in order to examine the effect of theory to practices of digitization. The complete survey of Lithuanian public museum is conducted $(\mathrm{N}=69)$, and the official statistics of Lithuanian museums is referred. The first analysis, Wilcoxon signed-rank test to examine the improvement of digitization environment in subjected museums after LIMIS implementation; as a result, the environment statistically significantly improved between 2008 and 2017. The second analysis, multivariate analysis of covariance (ANCOVA) examines the key factors for the quantity of digitization; as a total result amount of budget for each museum matters for an annual and total number of digitized exhibits. The discussion draws that LIMIS improved the practices of Lithuanian museum, though the significance of digitization in museums is still unstable.

\section{Digitalizační postupy v litevských muzeích po} implementaci LIMIS (2008-2017)

Tato studie se zaměřuje na LIMIS (Litevský integrální muzejní informační systém) a veřejná muzea v Litvě za účelem zkoumání vlivu teorie na praxi digitalizace. Studie uvádí kompletní přehled všech litevských veřejných muzeí zahrnutých do výzkumu $(\mathrm{N}=69)$ a také oficiální statistiku týkající se litevských muzeí. Jako první byl pro analýzu použit Wilcoxonův párový test, který měl prozkoumat zlepšení podmínek digitalizace v daných muzeích po zavedení LIMIS; výsledky ukázaly, že mezi lety 2008 a 2017 nastalo statisticky významné zlepšení sledovaného ukazatele. Druhá použitá analytická metoda, multivariantní analýza kovariace (ANCOVA), zkoumá faktory, které jsou klíčové z hlediska kvantity digitalizace; celkový výsledek ukázal, že roční i celkový úhrn digitalizovaných muzejních exponátů závisí primárně od výše rozpočtu jednotlivých muzeí. Ze závěrečné diskuse plyne, že LIMIS přispěl k zlepšení praxe litevského muzejnictví, i když význam digitalizace v muzeích je stále nestabilní.

\section{KLÍČOVÁ SLOVA:}

digital heritage - Lithuania LIMIS - Wilcoxon signed-rank test ANCOVA

digitální dědictví - Litva - LIMIS Wilcoxonův párový test - ANCOVA

\section{Accessibility and Digitization of Museums}

\subsection{Public access to museums and digitization}

Accessibility is one of the critical issues for museums. According to the definition by International Council of Museums, a museum is an institution, which is "open to the public," that "acquires, conserves, researches communicates and exhibits the tangible and intangible heritage." ${ }^{1}$ Museums usually "open" their exhibition room to show their collections. However, museums usually exhibit only a part of collections, due to the limitation of spaces for displaying. Therefore the large part of the collections, the non-exhibited part, are virtually closed to the public.

Digitization is one of the solutions to enhance public access to a museum: publicizing digital copies of exhibits via the internet enables more people to access the more significant part of the collection. The idea of ensuring accessibility by digital visiting emerged at the end of the twentieth century "in a European context at least." "2 Already in 2001, Lund Principle, a series of principles which established a commitment to the creation and management of European cultural e-content, agreed by European national experts and representatives, ${ }^{3}$ indicated that digitization of cultural objects is "a vital activity for providing improved access for the citizen." 4 Today, with the explosive

\footnotetext{
1 Museum Definition - ICOM. In International Council of Museums [online]. [accessed 2018-08-23]. Available from www: <https://icom. museum/en/activities/standards-guidelines/ museum-definition/>

2 PARRY, Ross. Digital heritage and the rise of theory in museum computing. Museum Management and Curatorship, 2005, vol. 20, no. 4, pp. 333-348.

3 Assessment Report on the Coordination of Digitisation in Europe [online]. Ministerial Network for Valorising Activities in Digitisation Plus, 2005 [accessed 2018-08-23]. Available from www: <http://www.minervaeurope.org/publications/ assessment.pdf $>$.

4 Progress report of the National Representatives Group: coordination mechanisms for digitisation policies and programmes 2002 [online]. European Commission: The Information Society Directorate-
} 
diffusion of the information and communication technology (further, ICT), the "virtual access" to museums seems to be increasing its importance.

Although digital accessibility itself is crucial, it does also matter whether museum specialists ${ }^{5}$ in each museum digitize their collection and prepare digital contents; if not, digital visitors will face an empty website or database. Thus, considering how each museum works on digitization is an important aspect to realize the better substantial public digital access to museums.

\subsection{Previous studies on digitization in museums}

The previous studies subjected to reveal digitization at museums were in either two levels of aspects: micro-level or macro-

-level. Micro-level aspect focuses on digitization attempts at each museum. For instance, an attempt at proposing three-dimensional in-house scanning at Smithsonian Institution's Museum Conservation Institute is considered, ${ }^{6}$ and integration of five different databases into one at the National Palace Museum in Taiwan is assessed. ${ }^{7}$ Although there are some exceptions, authors of micro-level studies are mainly ones who involved in the projects. ${ }^{8}$ On the

\footnotetext{
-General, 2003 [accessed 2018-08-23]. Available from www: <http://www.minervaeurope.org/ publications/globalreport/globalreppdf02/ appendici.pdf $>$.

5 In this article, the term "museum specialist" is used instead of "curator" This is because digitization involve broader work than "curator" in general, and also this term corresponds to a Lithuanian term "muziejininkas.

6 WACHOWIAK, Melvin J. and Basiliki Vicky KARAS. 3d Scanning and Replication for Museum and Cultural Heritage Applications. Journal of the American Institute for Conservation, 2009, vol. 48, no. 2, pp. 141-158.

7 WU, Shao-Chun. Systems integration of heterogeneous cultural heritage information systems in museums: a case study of the National Palace Museum. International Journal on Digital Libraries, 2016, vol. 17, no. 4, pp. 287-304.

8 More examples of micro-level digitization studies are: MASON, David D. M. and Conal MCCARTHY. Museums and the culture of new
}

other hand, macro-level studies focus on a theory or a notion of digitization, which involves several museums, and also, "strategic, co-ordinated and policy-

-motivated development" of museum computing. ${ }^{9}$ Public policies, which regulates digitization in cultural institutions, are one of the main subjects for this aspect. The dominant example is Europeana, ${ }^{10}$ the digital library launched in 2008, which is virtually the most extensive publicly driven cultural database which also includes collections of museums in Europe. The discourse of Europeana is analyzed by from the aspect of user's reuse policy. ${ }^{11}$ In most of the cases, macro-level studies fail to consider the specific influences to targeted museums or institutions. ${ }^{12}$

media: an empirical model of New Zealand museum websites. Museum Management and Curatorship, 2008, vol. 23, no. 1, pp. 63-80; MENNA, Fabio and Erica NOCERINO. Hybrid survey method for 3D digital recording and documentation of maritime heritage. Applied Geomatics, 2014, vol. 6, no. 2, pp. 81-93; MOHNS, William H. The Digital Archive and Catalogues of the Vanuatu Cultural Centre: Overview, Collaboration and Future Directions. In Working Together in Vanuatu [online]. ANU Press, 2011 [accessed 2018-08-26], Research Histories,

Collaborations, Projects and Reflections, pp. 141150. Available from www: <https://www.jstor. org/stable/j.ctt24h3dg.23 >; Characterising online museum users: a study of the National Museums Liverpool museum website. International Journal on Digital Libraries, 2018.

9 PARRY, Ross. Digital heritage and the rise of theory in museum computing. Museum Management and Curatorship, 2005, vol. 20, no. 4 pp. 333-348.

10 Welcome to Europeana Collections. In Europeana Collections [online]. [accessed 2018-08-23]. Available from www: <https://www. europeana.eu/portal/en/about.html>

11 VALTYSSON, Bjarki. Europeana. Information, Communication \& Society, 2012, vol. 15, no. 2, pp 151-170.

12 More examples of macro-level digitization studies are: BLUME, Jonas. Exploring the Potentials and Challenges of Virtual Distribution of Contemporary Art. In Digital Environments [online]. Transcript Verlag, 2017 [accessed 2018-08-26], Ethnographic Perspectives Across Global Online and Offline Spaces, pp. 97-116. Available from www: < https://www.jstor.org/stable/j. from www: < https://www.jstor.org/stable/j. and Paul COOKE. Experiencing the Digital World: The Cultural Value of Digital Engagement with Heritage. Heritage \& Society, 2016, vol. 9, no. 1, pp. 76-101; JONES, Michael. From catalogues to contextual networks: reconfiguring collection documentation in museums. Archives and Records, 2018, vol. 39, no. 1, pp. 4-20; Metadata management, interoperability and Linked Data publishing support for Natural History Museums. International Journal on Digital Libraries, 2014, vol. 14, no. 3, pp. 127-140; TAYLOR, Joel and Laura Kate GIBSON. Digitisation, digital interaction and social media: embedded barriers
Already from both macro- and micro-level phases, digitization in a museum is well discussed in the previous study, although the further up-to-date study is anticipated.

\subsection{Research subject}

Besides, this paper focuses on the connection between macro-level theory and micro-level practice: the relationship between legislative strategies, which regulate digitization, and practices at each institution, which is under those strategies. Considering the access of the public to museums by ICT, the coherence of theory and practices are essential. For museum (potential) visitor, theory without practice has no meaning; although bunch of unintegrated independent experiences, which is virtually unable to discover, is almost pointless for the Internet.

Lithuanian Integral Museum Information System (further, LIMIS) and Lithuanian public museums are selected as a research subject to examine from both micro-level and macro-level aspects. LIMIS is an integrated system for digital information of exhibits in Lithuanian museums. LIMIS is created according to the resolution by the Minister of Culture of the Republic of Lithuania in 2008, ${ }^{13}$ and currently managed by Lithuanian Art Museum. The subjects of this system are museums in Lithuania; almost every museum in Lithuania is already registered to this

to democratic heritage. International Journal of Heritage Studies, 2017, vol. 23, no. 5, pp. 408-420.

13 Dèl pavedimo Lietuvos dailès muziejui vykdyti projekta „Lietuvos integralios muziejų informacinés sistemos LIMIS diegimas Lietuvos muziejuose" ir lèšu skyrimo Lietuvos dailès muziejui 2009 metais investicinio projekto „Lietuvos integralios muziejų informacinés sistemos LIMIS diegimas Lietuvos muziejuose" parengimui [online]. Lietuvos Respublikos Kultūros Ministras, 7 July 2009 [accessed 2018-08-23]. Available from www: <http://wwwemuziejailt/wp-content/ uploads/2013/02/Del_LIMIS_diegimo_20111108 IV_6752.pdf $>$. 
system. ${ }^{14}$ Further details about LIMIS is displayed in the following section. Public museums are selected because it is relatively straightforward to see the effect of public policy in public museums compared to private ones.

Digitization at Lithuanian museums is already discussed from several points of view although LIMIS has not been the main subject yet. The transition of digital systems used in Lithuanian museums before LIMIS implemented, such as RIS and IRIS ${ }^{15}$ at Lithuanian Art Museum, is discussed, ${ }^{16}$ and the ICT use in Lithuanian museums is analyzed by applying "Hype-cycle" theory. ${ }^{17}$ Moreover, the strategies of Lithuanian digital cultural heritage decoded ${ }^{18}$, and more in general, the cultural policy in postSoviet Lithuania is discussed but digitization was not in its range. ${ }^{19}$ So far, the theory and a brief process of museum digitization in Lithuania is considered, however, its relationship with each museum's digitization practices are not yet discussed well.

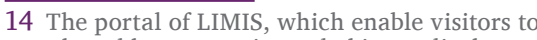
search and browse registered objects, displays the simple statistics such as number of registered items and museums. As of August 2018, 762,031 exhibits from 103 museums is registered and 256,949 items are publicly available. Welcome LIMIS [online]. [accessed 2018-08-23]. Available from www: < https://www.limis.lt/en/pradinis >

15 IRIS [online]. [accessed 2018-08-23]. Available from www: <http://www.rinkinys.ldm.lt/iris/ limis.htm>.

16 MUKIENĖ, Danutè. Lithuania: The Development of the Lithuanian Integral Information System for Automated Stocktaking, Digitisation, Preservation, Search, and Access to Museum Assets. Uncommon Culture, 2010, vol. 1 no. 1, pp. 136-141.

17 KAPLERIS, Ignas. Information and communication technologies (ICT) transference in Lithuanian museums [online]. 2014 [accessed 2018 -08-12]. Available from www: < https://digilib. phil.muni.cz/handle/11222.digilib/131396>.

18 LAUŽIKAS, Rimvydas and Regina VARNIENĖ-JANSSEN. Paveldas ir visuomenè: Lietuvos kultūros paveldo skaitmeninimo strateginès plètros gairès 2014-2020 metų programavimo laikotarpiui. Informacijos mokslai, 2014, vol. 69, pp. 118-143.

19 RINDZEVIČIŪTĖ, Eglè. Post-Soviet transformation of Lithuanian state cultural policy: the meanings of democratisation. Internationa Journal of Cultural Policy, 2012, vol. 18, no. 5, pp. 563-578.

\subsection{Research aim}

This paper aims to examine digitization practices in Lithuanian public museums after LIMIS implementation in two phases. The first aspect is whether digitizing conditions in Lithuanian public museums are improved compared with those before LIMIS introduced. A complete questionnaire survey of Lithuanian public museum $(\mathrm{N}=69$, covering about $94 \%$ of public museums in Lithuania) was conducted to grasp the current and so far digitizing conditions and environments at each museum. To verify the changes of digitization at museums, Wilcoxon signed rank test is applied to analyze collected data. The details of the questionnaire are to be referred to section 3 .

The second aspect is to examine what are the elements that affect the quantity of digitizing in each museum. Thus, multivariate analysis of covariance (ANCOVA) is selected as a mean for the analysis. Data for ANCOVA are selected from both official statistical data ${ }^{20}$ and the result of the complete questionnaire.

Two analysis above reveals whether and how LIMIS affected individual museums to advance the accessibility of museums. The reality of digitization in each museum is not as straightforward as just saying "let us digitize as much as possible." The discussion will clarify what is sufficient and what is necessary for digitization in Lithuania now. Although it is not as simple as a result in Lithuania could be directly applied to the cases in other countries, these

20 The Ministry of Culture publishes the annual statistical data of museums from 2008 to 2017 on its website. The data is based on the annual report from each museum: obligatory for public museums and optional for private museums. Muziejai ir galerijos | Lietuvos Respublikos kultūros ministerija [online]. Muziejų, Bibliotekų Ir Archyvu Skyrius [accessed 2018-08-23]. Available from www: < http://lrkm.lrv.lt/lt/veiklos-sritys/ muziejai-ir-galerijos $>$. analyses would be useful feedback from practices in museums to the theory.

\section{Overview of Lithuanian digital heritage policy and LIMIS}

This section depicts the overview of Lithuanian digital cultural policy and LIMIS, to provide the background of digitization in Lithuanian museums. The list of dominant official documents which is related to digitization in Lithuanian museums is shown as Fig. 1.

\subsection{Law of museums: definition of a museum}

A museum in Lithuania is defined by the law of museums enacted in 1995. ${ }^{21}$ This law primarily regulates Lithuanian museums' activities, that in Article 2 No. 1 demonstrate the definition of a museum (muziejus): "a legal entity acting as a budgetary, public institution or legal entity of another legal form established in accordance with the procedure established by law, whose main activity is to accumulate, protect, restore, investigate, exhibit and popularize material and spiritual cultural properties and natural objects." 22 This definition is basically consistent with the definition by ICOM $^{23}$ although the openness to the public is not directly referred. Digitization is not included in the definition, and also not yet a subject of this law, at the revision on July 1st, $2018 .^{24}$

\footnotetext{
21 Lietuvos Respublikos muzieju istatymas [online]. Lietuvos Respublikos Seimas, 8 June 1995 [accessed 2018-08-23]. Available from www: < https://www.e-tar.lt/portal/lt/legalAct/ TAR.863886C4199F/RIhKcePrma>.

22 ibid.

23 Museum Definition - ICOM. In International Council of Museums [online]. [accessed 2018 -08-23]. Available from www: <https://icom. museum/en/activities/standards-guidelines/ museum-definition/>.

24 Lietuvos Respublikos muzieju įstatymas [online]. Lietuvos Respublikos Seimas, 8 June 1995 [accessed 2018-08-23]. Available from www: < https://www.e-tar.lt/portal/lt/legalAct/ TAR.863886C4199F/RIhKcePrma>.
} 


\begin{tabular}{|c|c|c|c|c|}
\hline $\begin{array}{l}\text { Enactment } \\
\text { date }\end{array}$ & Title (Lithuanian) & Title (English) & Enacted by & $\begin{array}{l}\text { No. by the } \\
\text { institution }\end{array}$ \\
\hline $2005 / 8 / 25$ & $\begin{array}{l}\text { Dèl Lietuvos kultūros paveldo skaitmeninimo } \\
\text { koncepcijos patvirtinimo }\end{array}$ & $\begin{array}{l}\text { Approval of the Concept of Digitization of } \\
\text { Lithuanian Cultural Heritage }\end{array}$ & $\begin{array}{l}\text { The Government of the } \\
\text { Republic of Lithuania }\end{array}$ & 933 \\
\hline $2005 / 12 / 16$ & $\begin{array}{l}\text { Dèl Muziejuose esančių rinkinių apsaugos, } \\
\text { apskaitos ir saugojimo instrukcijos } \\
\text { patvirtinimo }\end{array}$ & $\begin{array}{l}\text { Instructions for the Protection, Accounting and } \\
\text { Storage of Collections in Museums }\end{array}$ & $\begin{array}{l}\text { The Ministry of Culture } \\
\text { of the Republic of } \\
\text { Lithuania }\end{array}$ & IV-716 \\
\hline $2008 / 5 / 8$ & $\begin{array}{l}\text { Dèl Lietuvos integralios muziejų informacinès } \\
\text { sistemos (LIMIS) diegimo ir muziejinių } \\
\text { vertybių skaitmeninimo projektų dalinio } \\
\text { finansavimo iš valstybės biudžeto léšų } 2008 \\
\text { metais }\end{array}$ & $\begin{array}{l}\text { The financing of the implementation of the } \\
\text { Lithuanian Integrated Museums Information } \\
\text { System (LIMIS) and the digitization of museum } \\
\text { valuables from the state budget in } 2008\end{array}$ & $\begin{array}{l}\text { The Ministry of Culture } \\
\text { of the Republic of } \\
\text { Lithuania }\end{array}$ & IV-241 \\
\hline $2009 / 5 / 20$ & $\begin{array}{l}\text { Dèl Lietuvos kultūros paveldo skaitmeninimo, } \\
\text { skaitmeninio turinio saugojimo ir prieigos } \\
\text { strategijos patvirtinimo }\end{array}$ & $\begin{array}{l}\text { The Approval of Digitization of Lithuanian } \\
\text { Cultural Heritage, Storage of Digital Content and } \\
\text { Access Strategy }\end{array}$ & $\begin{array}{l}\text { The Government of the } \\
\text { Republic of Lithuania }\end{array}$ & 493 \\
\hline $2009 / 12 / 21$ & $\begin{array}{l}\text { Lietuvos dailès muziejaus direktoriaus } \\
\text { issakymas dél Lietuvos dailès muziejaus filialo } \\
\text { Lietuvos muziejų informacijos, skaitmeninimo } \\
\text { ir LIMIS centras nuostatų patvirtinimo. }\end{array}$ & $\begin{array}{l}\text { The approval of the provisions of the Lithuanian } \\
\text { Museum of Information, Digitization and LIMIS } \\
\text { Branch of the Lithuanian Art Museum }\end{array}$ & Lithuanian Art Museum & V. $1-46$ \\
\hline $2010 / 2 / 26$ & $\begin{array}{l}\text { Dèl Lietuvos integralios muziejų informacinès } \\
\text { sistemos (LIMIS) nuostatų patvirtinimo }\end{array}$ & $\begin{array}{l}\text { The approval of the provisions of the Lithuanian } \\
\text { Integrated Museums Information System (LIMIS) }\end{array}$ & Lithuanian Art Museum & V. $1-25$ \\
\hline $2009 / 7 / 7$ & $\begin{array}{l}\text { Dèl pavedimo Lietuvos dailès muziejui } \\
\text { vykdyti projektą „Lietuvos integralios muziejų } \\
\text { informacinės sistemos LIMIS diegimas Lietuvos } \\
\text { muziejuose“ ir lèšų skyrimo Lietuvos dailès } \\
\text { muziejui } 2009 \text { metais investicinio projekto } \\
\text { "Lietuvos integralios muziejų informacinès } \\
\text { sistemos LIMIS diegimas Lietuvos muziejuose“ } \\
\text { parengimui }\end{array}$ & $\begin{array}{l}\text { Due to the assignment to the Lithuanian } \\
\text { Art Museum to implement the project } \\
\text { "Implementation of the Lithuanian Integrated } \\
\text { Museums Information System in the Lithuanian } \\
\text { Museums" and the allocation of funds to the } \\
\text { Lithuanian Art Museum in 2009, the preparation } \\
\text { of the investment project "Implementation of } \\
\text { the Lithuanian Integrated Museums Information } \\
\text { System LIMIS in Lithuanian Museums" }\end{array}$ & $\begin{array}{l}\text { The Ministry of Culture } \\
\text { of the Republic of } \\
\text { Lithuania }\end{array}$ & 345 \\
\hline $2010 / 1 / 7$ & $\begin{array}{l}\text { Dèl skaitmeninio turinio kūrimo, saugojimo } \\
\text { ir prieigos standartų ir norminių dokumentų } \\
\text { sąrašų patvirtinimo }\end{array}$ & $\begin{array}{l}\text { Approval of lists of digital content creation, } \\
\text { storage and access standards and regulatory } \\
\text { documents }\end{array}$ & $\begin{array}{l}\text { The Ministry of Culture } \\
\text { of the Republic of } \\
\text { Lithuania }\end{array}$ & IV-6 \\
\hline $2011 / 11 / 8$ & $\begin{array}{l}\text { Dèl Lietuvos integralios muziejų informacinès } \\
\text { sistemos LIMIS diegimo nacionaliniuose ir } \\
\text { respublikiniuose muziejuose }\end{array}$ & $\begin{array}{l}\text { The implementation of the Lithuanian Integrated } \\
\text { Museum Information System LIMIS in national } \\
\text { and republican museums }\end{array}$ & $\begin{array}{l}\text { The Ministry of Culture } \\
\text { of the Republic of } \\
\text { Lithuania }\end{array}$ & IV-675 \\
\hline $2014 / 10 / 6$ & $\begin{array}{l}\text { Dèl Kultūros objektų aktualizavimo 2014-2020 } \\
\text { metų programos patvirtinimo }\end{array}$ & $\begin{array}{l}\text { The approval of the program for updating } \\
\text { cultural objects for } 2014-2020\end{array}$ & $\begin{array}{l}\text { The Ministry of Culture } \\
\text { of the Republic of } \\
\text { Lithuania }\end{array}$ & IV-711 \\
\hline $2015 / 3 / 4$ & $\begin{array}{l}\text { Dėl skaitmeninio kultūros paveldo aktualinimo } \\
\text { ir išsaugojimo } 2015-2020 \text { metų programos } \\
\text { patvirtinimo }\end{array}$ & $\begin{array}{l}\text { Approval of the Program for the Modernization } \\
\text { and Preservation of the Digital Cultural Heritage } \\
\text { for } 2015-2020\end{array}$ & $\begin{array}{l}\text { The Ministry of Culture } \\
\text { of the Republic of } \\
\text { Lithuania }\end{array}$ & IV-153 \\
\hline
\end{tabular}

Fig. 1 List of documents related to digitization in Lithuanian museums

\subsection{A general guideline for museums: usage of computers for collection management}

One of the prominent guidelines of works in Lithuanian museums is "Instructions for the Protection, Accounting, and Storage of Collections in Museums" which is approved by Ministry of Culture of the Republic of Lithuania (further, the Ministry of Culture) in $2005 .{ }^{25}$ In order to provide

25 Dèl Muziejuose esančiu rinkinių apsaugos, apskaitos ir saugojimo instrukcijos patvirtinimo [online]. Lietuvos Respublikos Kultūros for museum employees with the competence of protection, accounting, storage, restoration and preservation of collections, this instruction includes about 600 provisions. This guideline approves the use of computers for collection management (rinkinu apskaita) in chapter V, No. 91, as, "The accounting of museum exhibits must be written and may be computerized." This statement

Ministerija, 16 December 2005 [accessed 2018-08-24]. Available from www: <https://www.e-tar.lt/portal/lt/legalAct/TAR.B4F13D66ADB6/ EGIRZCsFMm>. already existed at the point of enactment in 2005. Thus, in 2005, the role of digitizing for workers to manage collections is displayed as forms of the legal document. Nevertheless, even today, the main mean of management is a handwritten paper book; computers are still optional.

\subsection{Concepts and strategies of digitization in museums}

The first official concept of digital cultural heritage in Lithuania emerged in 2005 as a resolution 
by the Government of the Republic of Lithuania (Lietuvos Respublikos Vyriausybè, further, the Government). ${ }^{26}$ This concept has experienced two minor revision on November 17th, 2010 and January 21th, 2011, and still valid as of August 2018. ${ }^{27}$ As the title is "concept," this legal action is drawing the overview concepts, not the specific goals for museums. The remarkable feature of this concept is its aim that the integration into the context of Europe by digital heritage is claimed in chapter one, referring to the Lund Principle and Lund Action Plan. As a matter of fact, Lithuania joined the Minerva Project, the project launched by the Lund Action Plan from 2003, which implies that this concept is influenced by an external driving force.

More detailed goals for digital cultural heritage in each institution is first appeared in 2009 as "Digitization of Lithuanian Cultural Heritage, Storage of Digital Content and Access Strategy."28 In this strategy, the target value of digitized objects in memory institutions (library, archives, and museums), indicated to realize 110,000 objects until 2013 (increase 40,000 more digitized objects than in 2009). Also, the

\footnotetext{
26 Dèl Lietuvos kultūros paveldo skaitmeninimo koncepcijos patvirtinimo [online]. Lietuvos Respublikos Vyriausybė, 25 August 2005 [accessed 2018-08-25]. Available from www: <https://www.e-tar.lt/portal/lt/legalAct/TAR. E680D9093843/TAIS_391209>.

27 Dèl Lietuvos Respublikos Vyriausybès 2005 m. rugpjūčio 25 d. nutarimo Nr. 933 „Dél Lietuvos kultūros paveldo skaitmeninimo koncepcijos patvirtinimo" pakeitimo [online]. Lietuvos Respublikos Vyriausybe, 10 October 2010 [accessed 2018-08-25]. Available from www: <https://www.e-tar.lt/portal/lt/legalAct/ TAR.94218884CE22>; Dél Lietuvos Respublikos Vyriausybès $2005 \mathrm{~m}$. rugpjūčio 25 d. nutarimo Nr. 933 „Dèl Lietuvos kultūros paveldo skaitmeninimo koncepcijos patvirtinimo" pakeitimo [online]. Lietuvos Respublikos Vyriausybè, 17 January 2011 [accessed 2018-08-25]. Available from www: < https://www.e-tar.lt/portal/lt/legalAct/ TAR.7A9EE12C88C5>

28 Dél Lietuvos kultūros paveldo skaitmeninimo, skaitmeninio turinio saugojimo ir prieigos strategijos patvirtinimo [online]. Lietuvos Respublikos Vyriausybė, 20 May 2009 [accessed 2018-08-25]. Available from www: <https://www.e-tar. lt/portal/lt/legalAct/TAR.077D07A447E9/ TAIS_389331>.
}

creation of LIMIS is demonstrated, but the subsidizing for LIMIS from the state budget is already approved the year before, ${ }^{29}$ this strategy more focused on the possible quantity of digitizing objects than the brand new system. However, the specific role of museums is only indicated for the Lithuanian Art Museum.

\section{In 2015, digitization competence} center (skaitmeninimo kompetencijos centras) was proposed in "the Program for the Modernization and Preservation of the Digital Cultural Heritage for 2015-2020." 30 The competence center is appointed at two level (national and regional) in three sectors of memory institution (museums, libraries, archives). In the sector of museums, Lithuanian Art Museum is appointed as National Digitization Competence Center; National M. K. Ciurlionis Art Museum, Lithuanian Sea Museum, and Šiauliai „Aušros“ museum are appointed as Regional Digitization Competence Center. Nine functions of these competence centers indicated in the chapter IV No. 14 of the document, such as ensuring the quality and interoperability of digital content and encouraging the use of digitized cultural heritage content. ${ }^{31}$

\footnotetext{
29 Dél pavedimo Lietuvos dailès muziejui vykdyti projekta Lietuvos integralios muzieju informacines sistemos LIMIS diegimas Lietuvos muziejuose" sistemos LIMIS diegimas Lietuvos muziejuose“
ir léšu skyrimo Lietuvos dailes muziejui 2009 metais investicinio projekto „Lietuvos integralios muzieju informacinés sistemos LIMIS diegimas Lietuvos muziejuose" parengimui [online]. Lietuvos Respublikos Kultūros Ministras, 7 July 2009 [accessed 2018-08-23]. Available from www: < http://www.emuziejai.lt/wp-content/ uploads/2013/02/Del_LIMIS_diegimo_20111108 IV_6752.pdf $>$.

30 Dèl Skaitmeninio kultūros paveldo aktualinimo ir išsaugojimo 2015-2020 metu programos igyvendinimo priemoniu 2016-2018 metu plano patvirtinimo [online]. Lietuvos Respublikos Kultūros Ministerija, 10 November 2015 [accessed 2018-08-25]. Available from www: <https://www.e-tar.lt/portal/lt/legalAct/ a3a3a240886611e5b7eba10a9b5a9c5f/ uHTlvzmgwm>

31 ibid.
}

\subsection{LIMIS}

LIMIS, Lietuvos integrali muziejuc informacinè sistema (Lithuanian Integral Museum Information System), is the Lithuanian nationwide integrated system for digital information of exhibits in museums. The main three main function of LIMIS are: data collection as LIMIS-M subsystem, data preservation as LIMIS-C subsystem, and data publication as LIMIS-K subsystem. ${ }^{32}$ LIMIS-K subsystem is presented LIMIS Portal, ${ }^{33}$ the website which enables users to access data stored in LIMIS. The data is mainly uploaded to LIMIS-M by the specialists of each registered museum, and exported to a larger aggregator such as ePaveldas ${ }^{34}$ and EUROPEANA. ${ }^{35}$

Although the resolution by the Government indicated the implementation of LIMIS in 2009, ${ }^{36}$ the ministry-level documents did not regulate LIMIS. The resolution by the director of the Lithuanian Art Museum regulates the operation of LIMIS ${ }^{37}$ and Lithuanian Museums' Centre for Information, Digitization, and LIMIS $^{38}$ (hereafter LM CIDLIMIS).

32 LIMIS - Muziejiniu vertybiu skaitmeninimas [online]. [accessed 2018-08-25]. Available from www: <http://www.emuziejai.lt/limis/>

33 Welcome-LIMIS [online]. [accessed 2018-08-23]. Available from www: <https://www.limis.lt/ en/pradinis $>$

34 Paieška-epaveldas.lt [online]. [accessed 2018-08-25]. Available from www: <http://www. epaveldas.lt/home $>$.

35 Welcome to Europeana Collections. In Europeana Collections [online]. [accessed 2018-08-23]. Available from www: <https://www. europeana.eu/portal/en/about.html>.

36 Dèl Lietuvos kultūros paveldo skaitmeninimo, skaitmeninio turinio saugojimo ir prieigos strategijos patvirtinimo [online]. Lietuvos Respublikos

Vyriausybė, 20 May 2009 [accessed 2018-08-25]. Available from www: <https://www.e-tar. lt/portal/lt/legalAct/TAR.077D07A447E9/ TAIS 389331>.

37 Dél Lietuvos integralios muziejų informacine sistemos (LIMIS) nuostatu patvirtinimo [online] Lietuvos Dailès Muziejus, 26 February 2010 [accessed 2018-08-25]. Available from www: $<$ https://e-seimas.lrs.lt/portal/legalAct/lt/TAD/ TAIS.366735?jfwid $=$ q8i88mcvg $>$.

38 This resolution was approved on December 22nd, 2009 for the first time, and revised on July 7th, 2015. 
The manager and owner of LIMIS are Lithuanian Art Museum, and the specific department work with LIMIS is LM CID LIMIS. The total budget of LIMIS implementation, planned to be from 2009 to 2011, was 7,000,000 Litas (about 2,027,340 Euro), and 5,950,000 Litas (about 1,723,239 Euro) was subsidized by European Union. ${ }^{39}$ Today, already 765,395 exhibits from 103 museums are registered to LIMIS. ${ }^{40}$ Currently, 259,784 exhibits are available for public access, and 193,264 of them has a digital image. ${ }^{41}$

\section{Methodology}

\subsection{Data collection}

Data for this study are drawn from a complete questionnaire survey of Lithuanian public museums. Lithuanian public museums are the national museum (nacionalinis muziejus), state museum (respublikinis muziejus), and municipality museum (savivaldybès muziejus), which is defined in the article 4 of the law of museums. ${ }^{42}$ According to the Ministry of Culture, 4 national museums, 15 republic museums, 54 municipality museums in Lithuania, as of $2017 .^{43}$

Lietuvos dailès muziejaus direktoriaus ịsakymas dèl Lietuvos dailes muziejaus filialo Lietuvos muzieju informacijos, skaitmeninimo ir LIMIS centras nuostatu patvirtinimo. [online]. Lietuvos Dailès Muziejus, 7 July 2017 [accessed 2018-08-25]. Available from www: <http://old.ldm.lt/LDM/ PDF/V.1-46.pdf $>$.

39 Dèl Lietuvos kultūros paveldo skaitmeninimo, skaitmeninio turinio saugojimo ir prieigos strategijos patvirtinimo [online]. Lietuvos Respublikos Vyriausybè, 20 May 2009 [accessed 2018-08-25] Available from www: https://www.e-tar.lt/portal/ 1t/legalAct/TAR.077D07A447E9/TAIS_389331>.

40 Welcome - LIMIS [online]. [accessed 2018-08-23]. Available from www: <https://www.limis.lt/ en/pradinis $>$.

41 ibid.

42 Lietuvos Respublikos muzieju istatymas

[online]. Lietuvos Respublikos Seimas, 8 June

1995 [accessed 2018-08-23]. Available from www: <https://www.e-tar.lt/portal/lt/legalAct/ TAR.863886C4199F/RIhKcePrma>.

43 Muziejai ir galerijos | Lietuvos Respublikos kultūros ministerija [online]. Muzieju, Biblioteku Ir Archyvu Skyrius [accessed 2018-08-23]. Available from www: <http://lrkm.lrv.lt/lt/veiklos-sritys/ muziejai-ir-galerijos $>$.
The questionnaire to national museums are distributed in August 2018, to republic museums are in October 2018 and to municipality museums are in November 2018 via email. The responses are collected via email and postal mail $(\mathrm{N}=69$ responses). The responses include both English and Lithuanian, so the answers in Lithuanian are translated by the author.

The survey is on practices of digitization in each museum. Its purpose is to study how each museum executes digitization in everyday-job, and how does it change after the national strategies which implemented an idea of digital heritage in 2005, and implemented LIMIS in 2009. The questionnaire is created based on a pilot survey interview at three national museums. ${ }^{44}$ A part of the answers by national museums is from the answers to the interviews. The reliability of the questionnaire is evaluated before the distribution.

The questionnaire consists of four parts covering: the current situation in each museum, the current use of LIMIS in each museum, the year when each museum started using ICT related means, and the challenges of digitization in each museum. The first four parts are for responses by alternatives or short answers. The last part of the questionnaire is for open-ended free-text responses.

\subsection{Data analysis}

For the analysis of how the practices of digitizing changed after the national strategies, a Wilcoxon signed rank test is employed to test their changes (the significance level alpha $=0.05) .{ }^{45}$ For this analysis, the responses of "the year when

\footnotetext{
44 Interview date: from 10 February 2018 to 14 February 2018.

45 WILCOXON, Frank. Individual Comparisons by Ranking Methods. Biometrics Bulletin, 1945, vol. 1, no. 6 , pp. $80-83$.
}

each museum started using ICT related means" is converted into dummy variable in two ways.

- Converted answers to 1 if a specific event started before 2008, and otherwise convert to 0 .

- Convert answers to 1 if a specific event started before 2017, and otherwise convert to 0 .

The second aspect is to examine what are the elements that affect the quantity of digitizing in each museum. The hypothesis is that the scale and digitization conditions of museums, and whether a museum is a subject of first phase implementing LIMIS or not, has influenced to the quantity of digitization. This hypothesis is tested by multivariate analysis of covariance (ANCOVA). ${ }^{46}$ Therefore, the total and an annual number of digitized exhibits in each museum is the explained variable, and items listed below are the explanatory variables.

- The number of exhibits in each museum*

- The number of museum specialists*

- The total area of the museum $\left(\mathrm{km}^{2}\right)^{*}$

- The total amount of annual budget (Eur)*

- Does a museum have a special division for digitization $* * *$

- Does a museum hire any IT specialist**

- Does a museum include digitization in annual strategy***

- * is from statistics, ** is from the questionnaire

The software used for both analysis is Microsoft Excel with add-in software XLSTAT-Base.

46 KEITH, Timothy Z. Multiple Regression and Beyond: An Introduction to Multiple Regression and Structural Equation Modeling. London: Routledge, 2015. 


\section{Improvement of digitizing conditions in Lithuanian museums}

\subsection{Current digitization situation in Lithuanian museums}

Producing digital heritage is not a simple operation. Especially for an integrated system, participating institutions have to prepare digital contents according to the required standard and upload data to develop a rich database. The result of the complete survey, shown as a chart at Fig. 2, depicts an overview of practices in museums related to digitization in Lithuanian public museums.

information about its collection. Also, producing digital copies and meta-data is a necessary process for fulfilling LIMIS as a complete database. Moreover, already nearly $90 \%$ of museums are including digitization in their annual strategies. This result implies that, both in name and reality, digitization is regarded as one of the important issues for museums.

However, only $12 \%$ of respondents have a department for digitization, and only about one-third of museums hire the IT specialist. Therefore, the majority of museums are working on digitization without specialized department and IT

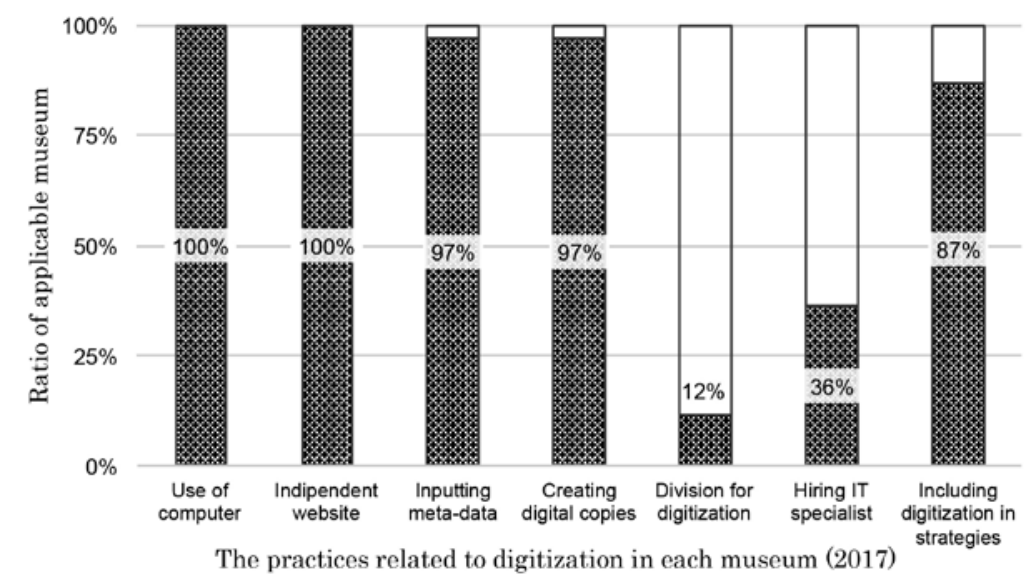

Fig 2. The chart of the overview of digitization situation at each museum in $2017(\mathrm{~N}=69)$

At the point of the survey, in 2017, every respondent uses computers in their museum and has its website. This result implies that nowadays computers have already become necessities for work in museums. They are not only using computers but also have their mean to publish their information to visitors via the internet. At least, visitors already can digitally communicate with public museums in Lithuania. Digitization, making digital copies and meta-data of own collection, is now a popular practice for most of the respondents. These activities are vital for each museum to prepare for publishing the specialist. Although IT specialists are not hired full-time or part-time in museums, from the supplemental notes in the questionnaire, it seems that they are consulting to external companies. Whether the specialized department or IT specialists exist or not matters for the quantity of digitization or not will be considered in the next section.

\subsection{The Wilcoxon signed-rank test result}

As it is indicated above, today, most public museums are at least on the start line of start digitization. The practices of digitization in
Lithuanian museum are seemed to be improved since LIMIS was launched. Therefore, to verify its improvement, statistical analysis to examine whether the transition happened or not is conducted. The summary of the result of the Wilcoxon signed-rank testis shown in Fig. 3.

The Wilcoxon signed rank test result of the changes of practices in museums before and after LIMIS implementation is straightforward. The situation of digitization in each respondent has statistically significant improvement from 2008 to 2017 at a $5 \%$ significance level $(\alpha=0.05)$. All of the elements indicated in the chart has experienced the growth in nine years after LIMIS started.

Usage of computers already achieved a high rate in 2009 , but still grew in the next eight years. On the other hand, specialized division for digitization marks the slow start and still not widespread. Before LIMIS implemented, only one respondent had a special division: this respondent is the one which now owns and manage LIMIS. Therefore, although only a few museums founded the digitization division, LIMIS implementation possibly stipulated some museums for its establishment.

Inputting meta-data and making digital copies are now both popular practice for many respondents, but in 2008, making digital copies are far less popular than in 2017. Meta-data is the description of each object, which is created as a text data by the relatively simple operation. On the other hand, making digital copies require a digital camera or scanner which involve rather complex technological means. In addition, taking digital photographs also need technique of photographer. Worthy of special mention that 


\begin{tabular}{|c|c|c|c|}
\hline \multirow[b]{2}{*}{ Practices in each museum } & \multicolumn{2}{|c|}{ Mean } & \multirow{2}{*}{$\begin{array}{c}\text { p-value } \\
\text { (Two-tailed) }\end{array}$} \\
\hline & 2008 & 2017 & \\
\hline Use of computer (dummy) & 0.884 & 1.000 & $0.0078 * *$ \\
\hline Start publishing website (dummy) & 0.565 & 1.000 & $<0.0001^{* *}$ \\
\hline Meta-data input (dummy) & 0.551 & 0.971 & $<0.0001^{* *}$ \\
\hline Creating digital copies (dummy) & 0.377 & 0.971 & $<0.0001^{* *}$ \\
\hline Establish specialized division for digitization (dummy) & 0.014 & 0.116 & $0.0156^{*}$ \\
\hline Hiring IT specialist (dummy) & 0.232 & 0.362 & $0.0039 * *$ \\
\hline Including digitization in strategies (dummy) & 0.101 & 0.870 & $<0.0001^{* *}$ \\
\hline
\end{tabular}

*5 \% significance level $(\alpha=0.05) * * 1 \%$ significance level $(\alpha=0.01)$

Fig. 3 The table of the result of Wilcoxon signed-rank test (2008-2017)

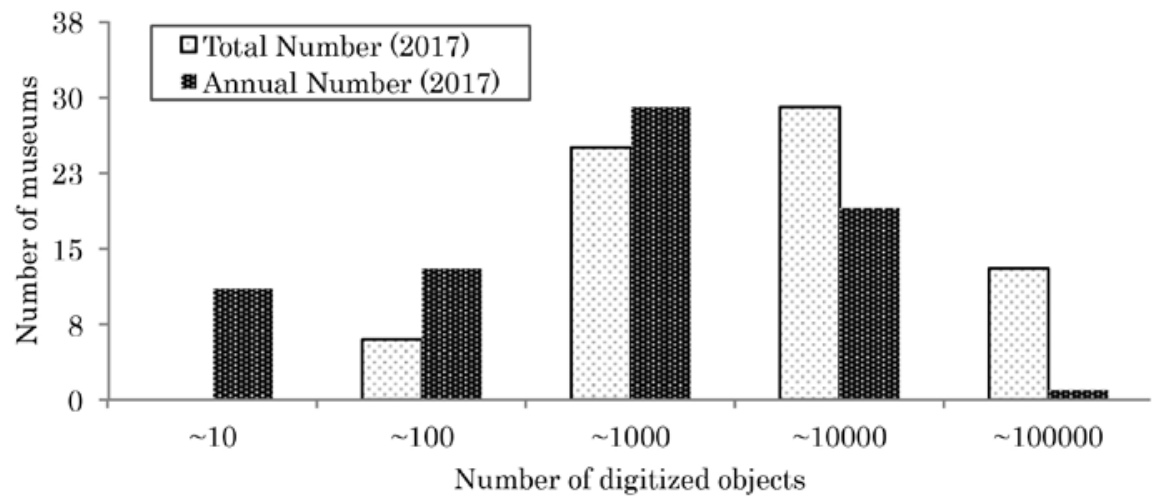

Fig. 4 Histogram of Quantity of Digitized Exhibits

the rate of digitization processes done in each museum, both with simple techniques and complicated techniques, is highly raised between 2009 and 2017.

The largest change has happened for the inclusion of digitization matters in annual strategies. Although not every museum includes digitization in their strategies, this implies that the nominal importance of digitization has been more admitted. Although it still marks a low rate in 2017, the rate of hiring IT specialists also improved. Compared to other practices, hiring specialist more demand the increase of budget and might be the most challenging issue for museums. Therefore, the statistically significant increases show that some museums are admitting its financial and nominal importance of digital technology for museums in the last nine years. The result of the complete questionnaire indicates that already most of the museums started digitization, although the majority of them do not have specialized department nor personnel for taking care of ICT matters. Moreover, the analysis of the questionnaire revealed that practices of digitization in Lithuania has improved since the launch of LIMIS and the improvement is statistically significant (significance level $\alpha=0.05$ ). However, the analysis shows only the fact that they increased; whether it is increased by the natural process of ICT innovation or the effect of LIMIS is not shown yet. This subject will be discussed in the further section.

\section{Key factors for the quantity of digitization in Lithuanian museums}

\subsection{Quantity of digitization}

How many exhibits do museums have digitized so far? The previous section indicated the result of analysis of the complete questionnaire to Lithuanian public museums, which mainly shows whether they do digitize or do not digitize. However, quantity is also the essential matter for digitization. Since thousands and millions of exhibits are preserved in museums, the large amount of digitization is required to realize better public access to museum collections.

According to the statistics published by the Ministry of Culture, the annual and a total number of digitized exhibits varies by museums. Some digitize less than 10 objects per year, but on the other hand, some digitize more than 10,000 objects per year. It is true that most museums work on digitization, but the workload depends on museums. The Fig. 4 shows the histogram of the number of digital objects.

To digitize is important, but to digitize the more is the better. Thus, the fundamental factors that relate to the quantity of digitization need to be considered. The possible factors are the scale of the museum (the number of exhibits in their collection, the physical size of the museum, the number of museum specialists, and the amount of annual budget) and the practices of digitization which is not applicable to all museum (Does a museum has a special division for digitization, does a museum hire any IT specialist, does a museum include digitization in annual strategy). 


\begin{tabular}{|c|c|}
\hline Observations & 69.000 \\
\hline Sum of weights & 69.000 \\
\hline $\mathrm{DF}$ & 60.000 \\
\hline $\mathrm{R} 2$ & $0.935^{\mathrm{a}}$ \\
\hline Adjusted R2 & 0.926 \\
\hline MSE & 23424902.216 \\
\hline RMSE & 4839.928 \\
\hline \multicolumn{2}{|c|}{$\begin{array}{l}\text { a. Predictors: (Constant), Total number of } \\
\text { objects in each collection, Number of museum } \\
\text { specialists (Muziejininkas), Museum premises } \\
\text { area }\left(\mathrm{km}^{2}\right) \text {, Total budget amount (Eur), } \\
\text { National/state museum dummy, Specialized } \\
\text { department for digitization dummy, Hiring } \\
\text { IT specialist dummy, Including digitization in } \\
\text { strategy dummy }\end{array}$} \\
\hline
\end{tabular}

Fig. 5 Goodness of fit statistics of the regression of The total number of digitized exhibits (2017) on 8 related factors

\begin{tabular}{|c|c|c|c|c|c|}
\hline \multicolumn{6}{|c|}{ ANOVA $^{\mathrm{b}}$} \\
\hline Source & DF & Sum of squares & Mean squares & $\mathrm{F}$ & $\operatorname{Pr}>F$ \\
\hline Model & 8 & 20072091935.321 & 2509011491.915 & 107.109 & $<0.0001 \mathrm{a}$ \\
\hline Error & 60 & 1405494132.968 & 23424902.216 & & \\
\hline Corrected Total & 68 & 21477586068.290 & & & \\
\hline \multicolumn{6}{|c|}{ Computed against model $Y=$ Mean $(Y)$} \\
\hline \multicolumn{6}{|c|}{$\begin{array}{l}\text { a. Predictors: (Constant), Total number of objects in each collection, Number of museum specialists } \\
\text { (Muziejininkas), Museum premises area }\left(\mathrm{km}^{2}\right) \text {, Total budget amount (Eur), National/state museum } \\
\text { dummy, Specialized department for digitization dummy, Hiring IT specialist dummy, Including } \\
\text { digitization in strategy dummy } \\
\text { b. Dependent variable: The total number of digitized exhibits }\end{array}$} \\
\hline
\end{tabular}

Fig. 6 Test of statistical significance of the regression of The total number of digitized exhibits (2017) on 8 related factors

\begin{tabular}{|c|c|c|c|c|c|}
\hline \multicolumn{6}{|c|}{ Coefficientsa } \\
\hline \multirow[b]{2}{*}{ Source } & \multicolumn{2}{|c|}{ Unstandardized coefficients } & \multirow{2}{*}{$\begin{array}{c}\text { Standardized coefficients } \\
\text { Value }\end{array}$} & \multirow[b]{2}{*}{$\mathrm{t}$} & \multirow[b]{2}{*}{$\operatorname{Pr}>|t|$} \\
\hline & Value & Standard error & & & \\
\hline (Constant) & -5112.807 & 2335.671 & & -2.189 & 0.032 \\
\hline Total number of objects in each collection & 0.018 & 0.004 & 0.183 & 3.983 & 0.000 \\
\hline Number of museum specialists (Muziejininkas) & 248.537 & 69.132 & 0.412 & 3.595 & 0.001 \\
\hline Museum premises area, $\mathrm{km}^{2}$ & 0.494 & 0.305 & 0.179 & 1.616 & 0.111 \\
\hline Total budget amount (Eur) & 0.003 & 0.000 & 0.351 & 6.808 & $<0.0001$ \\
\hline National/state museum dummy & 315.169 & 1750.866 & 0.008 & 0.180 & 0.858 \\
\hline Specialized department for digitization dummy & 2684.153 & 2137.080 & 0.049 & 1.256 & 0.214 \\
\hline Hiring IT specialist dummy & 690.184 & 1367.797 & 0.019 & 0.505 & 0.616 \\
\hline Including digitization in strategy dummy & -28.983 & 1797.149 & -0.001 & -0.016 & 0.987 \\
\hline
\end{tabular}

Fig. 7 Unstandardized and standardized regression coefficients for the regression of The total number of digitized exhibits (2017) on 8 related factors

\subsection{Influential factors for total number of digitized exhibits (2017)}

The first analysis was designed to determine the influence, to a total number of digitized exhibits, of the practices of digitization which is not applicable to all museum, while controlling for the scale of the museum. The total number of digitized exhibits in 2017 were regressed on Total number of objects in each collection, Number of museum specialists (Muziejininkas), Museum premises area $\left(\mathrm{km}^{2}\right)$, Total budget amount (Eur), National/state museum (dummy), Specialized department for digitization (dummy), Hiring IT specialist (dummy), and Including digitization in strategy (dummy). The results of multiple regression, are shown as Fig. 5, Fig. 6, Fig. 7, and Fig. 8.

The overall multiple regression was statistically significant (Adjusted $R^{2}=.926, F[8,60]=$ 107.109, $p=<.0001$ ), and eight variables accounted for $93 \%$ of the variance in the total number of digitized exhibits in 2017. Each of three independent variables (Total number of objects in each collection, Number of museum specialists (Muziejininkas), the Total budget amount (Eur)) also had a statistically significant effect on the total number of digitized exhibits in 2017.

The unstandardized regression coefficient $(b)$ for a total number of objects was .018 $(t[60]=3.983$, $p=.00018$ ), meaning that for every 1,000 additional exhibits in the museum, the total number 
of digitized exhibits increase by 18 objects, controlling for other seven factors. The larger effect is the number of museum specialists (Muziejininkas) $(b=$ 248.537, $t[60]=3.595, p=.001$ ). This finding suggests that, for each additional museum specialist in the museum, the total number of digitized exhibits increase by 248.537 objects, controlling for other seven factors. Moreover, the significant but scarce influence is drawn by the total budget amount (Eur) $(b=.003, t[60]=6.808$, $p=<.0001)$. This result implies that for each additional 1,000 Eur for the annual budget, the total number of digitized exhibits increase by 3 objects, controlling for other seven factors.

The result suggests that indeed the scale of the museum has an important influence on the total number of digitized exhibits. On the other hand, each practice of digitization which is not applicable to all museum is doesn' t have a significant effect, controlling for other seven factors. Although the total number of exhibits and the annual budget amount has a significant effect, thousands of additional objects or additional euros are required to increase only a few for the total amount of digitized exhibits. Therefore, this result implies that instead of establishing a specialized department for digitization or hiring IT specialists, hiring additional museum specialist had a larger effect on digitization so far.

\subsection{Influential factors for annual number of digitized exhibits (2017)}

The second analysis was designed to determine the influence, to an annual number of digitized exhibits, of the practices of digitization which is not applicable to all museum, while controlling

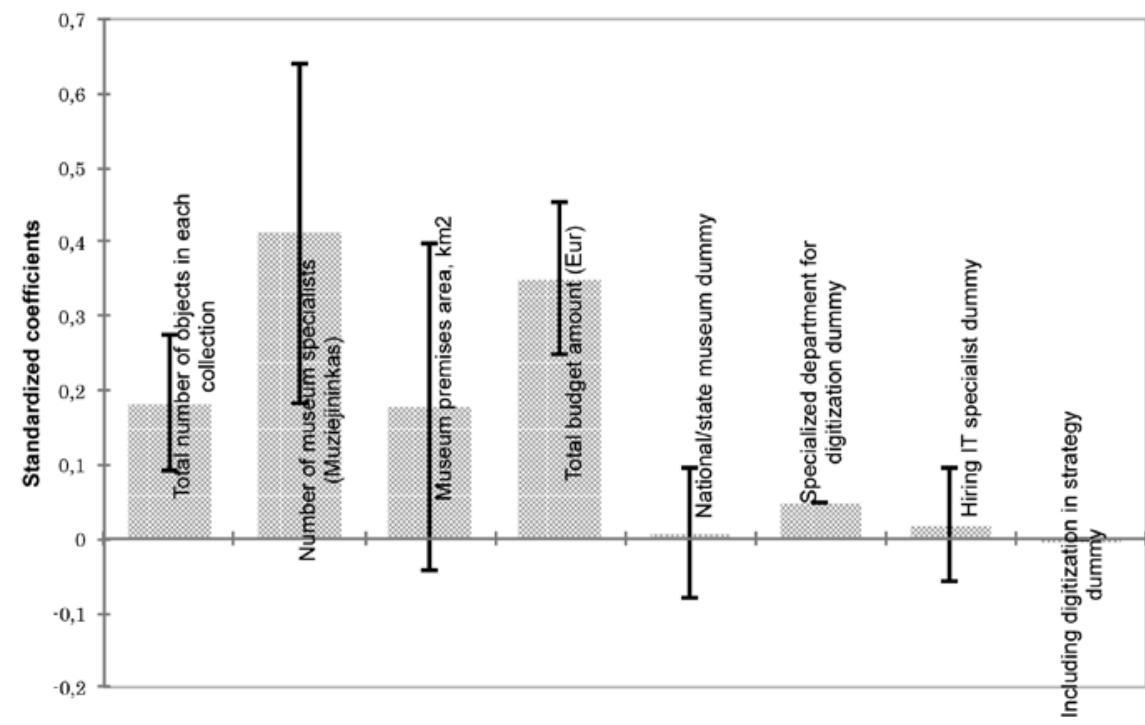

Fig. 8 Chart: Standardized coefficients (95\% conf. interval) for the regression of the total number of digitized exhibits (2017) on 8 related factors

\begin{tabular}{|c|c|}
\hline Observations & 69.000 \\
\hline Sum of weights & 69.000 \\
\hline $\mathrm{DF}$ & 60.000 \\
\hline $\mathrm{R} 2$ & $0.709^{\mathrm{a}}$ \\
\hline Adjusted R2 & 0.671 \\
\hline MSE & 1515578.871 \\
\hline RMSE & 1231.088 \\
\hline \multicolumn{2}{|c|}{$\begin{array}{l}\text { a. Predictors: (Constant), Total number of } \\
\text { objects in each collection, Number of museum } \\
\text { specialists (Muziejininkas), Museum premises } \\
\text { area }\left(\mathrm{km}^{2}\right) \text {, Total budget amount (Eur), } \\
\text { National/state museum dummy, Specialized } \\
\text { department for digitization dummy, Hiring } \\
\text { IT specialist dummy, Including digitization in } \\
\text { strategy dummy }\end{array}$} \\
\hline
\end{tabular}

Fig. 9 Goodness of fit statistics of the regression of the annual number of digitized exhibits (2017) on 8 related factors

for the scale of the museum. The annual number of digitized exhibits in 2017 were regressed on Total number of objects in each collection, Number of museum specialists (Muziejininkas), Museum premises area $\left(\mathrm{km}^{2}\right)$, Total budget amount (Eur), National/state museum (dummy), Specialized department for digitization (dummy), Hiring IT specialist (dummy), and Including digitization in strategy (dummy). The results of multiple regression,

\begin{tabular}{|l|c|}
\hline Observations & 69.000 \\
\hline Sum of weights & 69.000 \\
\hline DF & 60.000 \\
\hline R2 & $0.709^{\mathrm{a}}$ \\
\hline Adjusted R2 & 0.671 \\
\hline MSE & 1515578.871 \\
\hline RMSE & 1231.088 \\
\hline $\begin{array}{l}\text { a. Predictors: (Constant), Total number of } \\
\text { objects in each collection, Number of museum } \\
\text { specialists (Muziejininkas), Museum premises } \\
\text { area (km2), Total budget amount (Eur), } \\
\text { National/state museum dummy, Specialized } \\
\text { department for digitization dummy, Hiring } \\
\text { IT specialist dummy, Including digitization in } \\
\text { strategy dummy }\end{array}$
\end{tabular}

Fig. 10 Test of statistical significance of the regression of the annual number of digitized exhibits (2017) on 8 related factors

are shown as Fig. 9, Fig. 10 Fig. 11, and Fig. 12.

The overall multiple regression was statistically significant (Adjusted $R^{2}=.671, F[8,60]=$ $18.310, p=<.0001$ ), and eight variables accounted for $67 \%$ of the variance in the annual number of digitized exhibits in 2017. Each of two independent variables (Total budget amount (Eur), National/ state museum (dummy)) also had a statistically significant effect 


\begin{tabular}{|c|c|c|c|c|c|}
\hline \multicolumn{6}{|c|}{ Coefficients $^{\mathrm{a}}$} \\
\hline \multirow[b]{2}{*}{ Source } & \multicolumn{2}{|c|}{ Unstandardized coefficients } & \multirow{2}{*}{$\begin{array}{c}\text { Standardized coefficients } \\
\text { Value }\end{array}$} & \multirow[b]{2}{*}{$\mathrm{t}$} & \multirow[b]{2}{*}{$\operatorname{Pr}>|t|$} \\
\hline & Value & Standard error & & & \\
\hline (Constant) & 1145.984 & 594.103 & & 1.929 & 0.058 \\
\hline Total number of objects in each collection & -0.001 & 0.001 & -0.110 & -1.138 & 0.260 \\
\hline Number of museum specialists (Muziejininkas) & 24.290 & 17.584 & 0.334 & 1.381 & 0.172 \\
\hline Museum premises area, $\mathrm{km}^{2}$ & -0.045 & 0.078 & -0.136 & -0.583 & 0.562 \\
\hline Total budget amount (Eur) & 0.001 & 0.000 & 0.612 & 5.629 & $<0.0001$ \\
\hline National/state museum dummy & -1340.247 & 445.352 & -0.281 & -3.009 & 0.004 \\
\hline Specialized department for digitization dummy & 8.938 & 543.590 & 0.001 & 0.016 & 0.987 \\
\hline Hiring IT specialist dummy & 493.682 & 347.914 & 0.111 & 1.419 & 0.161 \\
\hline Including digitization in strategy dummy & 13.300 & 457.124 & 0.002 & 0.029 & 0.977 \\
\hline
\end{tabular}

Fig. 11 Unstandardized and standardized regression coefficients for the regression of The annual number of digitized exhibits (2017) on 8 related factors

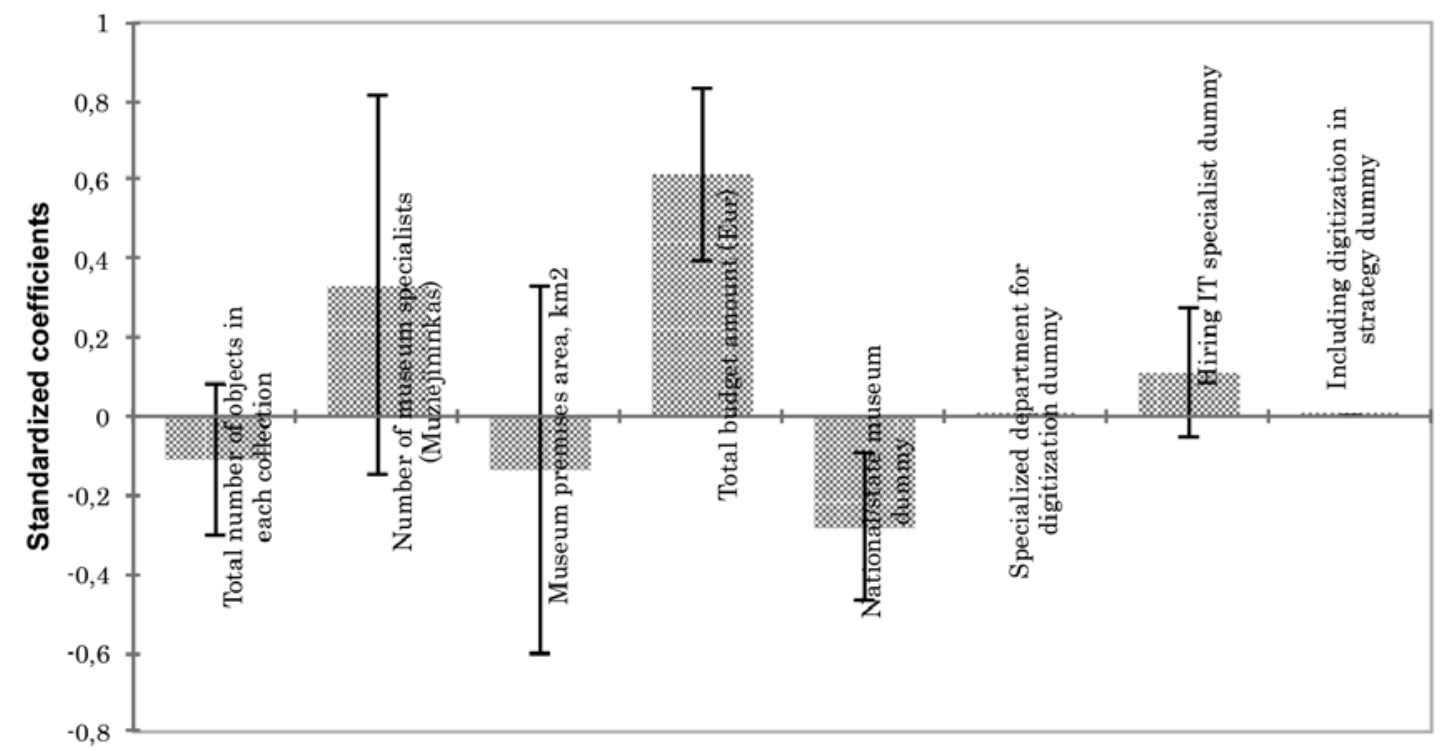

Fig. 12 Chart: Standardized coefficients (95\% conf. interval) for the regression of The annual number of digitized exhibits (2017) on 8 related factors

on the total number of digitized exhibits in 2017.

The positive effects is the total budget amount (Eur) $(b=.001, t[60]=.612, p=$ $<$.0001). This result implies that for each additional 1,000 Eur for the annual budget, the total number of digitized exhibits increase by 1 object, controlling for the other seven factors. The negative effect is National/state museum (dummy) $(b=-1340.247, t[60]=-3.009$, $p=.004$ ). This finding suggests that, if the museum is a national or a state museum, the total number of digitized exhibits are less by 248.537 than municipality museums, controlling for other seven factors.

The results suggest that the total budget amount has an only positive influence on digitization quantity out of eight factors. As it is visualized in Fig. 12, standardized coefficients of the total budget amount are the highest, compared to another variant. Although, only one digitized exhibit increases for every 1,000 Euro, which does not seem like increasing the budget is a straightforward strategy for increasing digitization budget. Thus, it implies that the ratio of the budget for museums which is used for digitization is not at a high rate.

Comparing the results of the regression of the total and an annual number of digitized exhibits, differences between accumulation from the past and 
the current ongoing situation is highlighted. The largest difference is that the scale of museums are more likely to affect the total number of digitized exhibits, but less likely to influence annual number. Especially, for the annual number of digitized exhibits, national/state museums tend to digitize statistically significantly less than municipality museums. In other words, in 2017, the gap of scale does not necessarily connect to the gap of digitization. Although, the annual amount of budget is a significant factor for both total and an annual number of digitized exhibits.

The hypothesis for the analysis that the scale of the museum and the practices of digitization for which is not applicable to all museum influences the quantity of digitization should be rejected. Not all of the factors are significant to explain the total and an annual number of digitized exhibits in each museum; only the annual budget amount matters for both the total and an annual number of digitized exhibits.

\section{Discussion:}

\section{How LIMIS influenced museums}

\subsection{Improvement of digitization in Lithuanian museums}

The result of the questionnaire revealed the brief usage of digital means in museums in Lithuania. Currently, Lithuanian public museums are fully equipped with computers, which are necessary devices to realize digitization. Having a website of own institution is already popular for museums as well. Also, in almost all museums, the creation of digital copies of own collection and its metadata is in their duties. Moreover, most of them include digitization of their annual strategies. Thus, almost every museum in Lithuania, as of 2017 , is at least at the starting point of utilizing ICT.
However, still, most museums do not have a specialized division for digitization, nor having IT specialist inside museums.

The ratio of digitization practices in museums (computers use, having website, meta-data input, digital copies creation, specialized division for digitization, IT specialist or includes digitization in annual strategies) increased between 2009 and 2017. The Wilcoxon signed-rank test proved that these changes are statistically significant at 5 percent level. Therefore, the environment for digitizing in each public museum in Lithuania has improved in a decade after LIMIS implementation.

Hence, enriching the environment for digitization is no more the issue for public museums in Lithuania: how to advance more digitization is the current critical question them. One index, which explains the digitization procedure in each museum, is the number of digitized exhibits. According to the multiple regression, indicated in the previous section, the total amount of annual budget matters both the total and annual quantity of digitized exhibits, as of 2017.

\subsection{Natural process or LIMIS}

Although the result of the Wilcoxon signed rank test shows that there are statistically significant changes between 2009 and 2017, this result doesn' $t$ indicate the reason of the change. Therefore, the causal relation between LIMIS implementation and the improvement of a situation is not displayed. In the past decade, ICT and its instruments innovate and spread day by day that the effect of this "natural process" of advancing technologies in museums is almost impossible to measure. Therefore, the "natural process" of technological innovation is also likely that it boosted digitization in Lithuanian public museums.
It is reasonable to think the increase of usage of computers and publishing website is driven by the "natural process." Not only in museums but in general, it seems like more people are using computers and accessing websites: it is more convenient for any workers to prepare documents than write everything by hand and easier to have websites to communicate with visitors. In other words, these two factors make the work in the museum more or less efficient and comfortable.

However, the creation of digital copies and preparation of meta-data have different nature. They weren' $t$ tasks for museums several decades ago: at an initiation, they are additional tasks for the museum. Although a museum specialist in a museum could come up with the idea of enhancing accessibility through digitization, a system like LIMIS would be often not affordable for small museums with a small budget. Therefore, the possibility of digital copies and meta-data naturally integrate into museums is lower than that of computers and websites.

Thus, the fact itself that almost every public museum in Lithuania, including relatively small ones, are now creating digital copies and preparing meta-data shows the external influence, which is larger than a simple natural process. In the last decade, the largest difference happened for digitization in the museum is the launch of LIMIS. Accordingly, the increase of digitization in many public museums in Lithuania could be concluded as a result of implementing LIMIS.

\subsection{Specialized departments: Unnecessary or insufficient?}

As it is referred at section 6.1, a specialized department for 
digitization is not yet popular in many Lithuanian public museums. Compared to other elements, such as the use of computers or creating digital copies, the establishment of the department is not straightforward: they need to increase the total number of museum specialist or decrease the workers for other sections. Whether to hire IT specialists or not has the similar feature. Realizing these two factors requires relatively large financial or work-load burden.

This infers several possibilities: most of the museums do not consider (yet) that establishing a new department for digitization is important, or simply they cannot afford. Since the budget in each museum is limited, therefore the trade-off between digitization and other functions of a museum is also likely to happen.

According to the multiple regression analysis in section 5 , controlling the scale of museums, a specialized department of digitization is not a significant factor for the quantity of digitization in each museum. Therefore, it is also possible that such a department is unnecessary at the moment. In other words, most of the museums already smoothly perform digitization so that a specialized department is not required.

On the other hand, the free-text answers in the questionnaire which asked "what is the difficulties for digitization?" reveal another perspective. The major answers from municipality museums are roughly classified into three: lack of devices for digitization, lack of human resource, and lack of resource in general. For the establishment of a specialized department for digitization, both workers and devices are necessary. Therefore, it is possible that the museum simply cannot afford the digitization department.
These two split phases of a specialized department of digitization are the reflection of the uncertain value of digitization as a function of a museum. Although digitization is likely to play an important role in enhancing museum accessibility, still digitization is an optional duty; it is rarely referred to as a main function of museums. Therefore, as it is depicted above, a specialized department of digitization is both unnecessary and insufficient.

\subsection{Limitation}

This study has two limitations: the reason why LIMIS had influences is not revealed, and the public's access to the museum itself is not evaluated. Both limitations are due to the methodology of this study; the survey was designed to reveal the tendency of whole museums in Lithuania, focusing on the museum's internal practices. In other words, the aspect of how each museum's staffs are working with digitization is not covered by this study. Therefore, there is a need for studying in-depth of each museum's practice according to the result of this survey. Also, how public access to digitized exhibits is also a critical point of view in the further studies.

\section{Conclusion}

Digitization of collections in museums is an essential solution for empowering public access to museums. The promotion of digitization in each museum is a critical factor for museum accessibility via digital technology. Thus, this study focused on LIMIS (Lithuanian Integral Museum Information System) and Lithuanian public museums, in order to examine the effect of theory to practices of digitization.

Lithuanian digital cultural heritage is first recognized as a target of national strategies in 2005, that "concept" of digital heritage is approved by the Government this year. In 2009, strategy with a target number of digitization in museums, libraries, and archives was approved. The creation of LIMIS is indicated in this strategy. The following strategies became more detailed than the strategy in 2009. However, LIMIS implementation started in 2009 seems to be the most critical Turing point for digitization in museums.

Data collection for the analysis according to the research aim is conducted in two ways. One is the complete survey of Lithuanian public museums $(\mathrm{N}=69)$. This survey covered more than $94 \%$ of Lithuanian public museums. Another data source is the official statistics data of 2017 published by the Ministry of Culture. Collected data were analyzed in two statistical methods: Wilcoxon signed-rank test to examine the improvement of digitization environment in subjected museums after LIMIS implementation in 2009, and ANCOVA to examine the key factors for the number of digitized exhibits. The Wilcoxon signed-rank test revealed that practices of digitization in Lithuanian public museums are improved from 2008 to 2017. ANCOVA revealed that the total amount of budget for each museum statistically significantly matters for an annual and a total number of digitized exhibits in each museum.

The discussion draws that LIMIS improved the digitization practices of Lithuanian museum. Because ICT innovates and disseminates day by day, the progress of digitization in the museum could be stated as a result of this natural process of its innovation. Because the work for digitizing exhibits in museums is not necessarily comfortable and convenient for the museum, so it is unlikely to spread to museums 
naturally. Thus the improvement of digitization environment, which is proved to be statistically significant, could be inferred as a result of LIMIS implementation. However, establishing of a digitization department in museums is still not popular, because already many museums digitize without such a department, and also because many museums cannot afford it. Taking this state into consideration, the significance of digitization in museums is still unstable.

\section{ACKNOWLEDGEMENTS}

The author would like to thank Donatas Snarskis and LIMIS center at Lithuanian Art Museum for providing with information about LIMIS, Vilma Leonavičienè for advice on Lithuanian language use for the survey, and all of the public museums in Lithuania for their kind cooperation to the questionnaire.

\section{REFERENCES:}

Assessment Report on the Coordination of Digitisation in Europe [online]. Ministerial Network for Valorising Activities in Digitisation Plus, 2005 [accessed 2018-08-23]. Available from www: <http://www.minervaeurope. org/publications/assessment.pdf $>$.

BLUME, Jonas. Exploring the Potentials and Challenges of Virtual Distribution of Contemporary Art. In Digital Environments [online]. Transcript Verlag, 2017 [accessed 2018-08-26], Ethnographic Perspectives Across Global Online and Offline Spaces, pp. 97-116. Available from www: <https://www. jstor.org/stable/j.ctv1xxrxw.10>. ISBN 978-3-8376-3497-6.

Dèl Lietuvos integralios muziejų informaciness sistemos (LIMIS) nuostatu patvirtinimo [online]. Lietuvos Dailès Muziejus, 26 February 2010 [accessed 2018-08-25]. Available from www: <https://e-seimas.lrs.lt/portal/legalAct/lt/TAD/ TAIS.366735?jfwid $=\mathrm{q} 8 \mathrm{i} 88 \mathrm{mcvg}>$.
Dèl Lietuvos kultūros paveldo skaitmeninimo koncepcijos patvirtinimo [online]. Lietuvos Respublikos Vyriausybe், 25 August 2005 [accessed 2018-08-25]. Available from www: <https:// www.e-tar.lt/portal/lt/legalAct/TAR. E680D9093843/TAIS_391209>.

Dèl Lietuvos kultūros paveldo skaitmeninimo, skaitmeninio turinio saugojimo ir prieigos strategijos patvirtinimo [online]. Lietuvos Respublikos Vyriausybè, 20 May 2009 [accessed 2018-08-25]. Available from www: <https://www.e-tar.lt/portal/ lt/legalAct/TAR.077D07A447E9/ TAIS_389331>.

Dèl Lietuvos Respublikos Vyriausybès $2005 \mathrm{~m}$. rugpjūčio $25 \mathrm{~d}$. nutarimo Nr. 933 „Dèl Lietuvos kultūros paveldo skaitmeninimo koncepcijos patvirtinimo" pakeitimo [online]. Lietuvos Respublikos Vyriausybè, 10 November 2010 [accessed 2018-08-25]. Available from www: <https://www.e-tar.lt/portal/lt/ legalAct/TAR.94218884CE22>.

Dél Lietuvos Respublikos Vyriausybès 2005 m. rugpjūčio 25 d. nutarimo Nr. 933 „Dèl Lietuvos kultūros paveldo skaitmeninimo koncepcijos patvirtinimo" pakeitimo [online]. Lietuvos Respublikos Vyriausybè, 17 January 2011 [accessed 2018-08-25]. Available from www: $<$ https://www.e-tar.lt/portal/lt/ legalAct/TAR.7A9EE12C88C5>.

Dèl Muziejuose esančių rinkinių apsaugos, apskaitos ir saugojimo instrukcijos patvirtinimo [online]. Lietuvos Respublikos Kultūros Ministerija, 16 December 2005 [accessed 2018-08-24]. Available from www: <https:// www.e-tar.lt/portal/lt/legalAct/TAR. B4F13D66ADB6/EGlRZCsFMm >

Dèl pavedimo Lietuvos dailes muziejui vykdyti projekta „Lietuvos integralios muzieju informacines sistemos LIMIS diegimas Lietuvos muziejuose" ir léšu skyrimo Lietuvos dailes muziejui 2009 metais investicinio projekto „Lietuvos integralios muzieju informacinés sistemos LIMIS diegimas Lietuvos muziejuose" parengimui [online]. Lietuvos Respublikos Kultūros Ministras, 7 July 2009 [accessed 2018-08-23]. Available from www: $<$ http://www.emuziejai.lt/wpcontent/uploads/2013/02/Del_LIMIS_ diegimo_20111108_IV_6752.pdf >
Dèl Skaitmeninio kultūros paveldo aktualinimo ir išsaugojimo 2015-2020 metu programos igyvendinimo priemoniu 20162018 metu plano patvirtinimo [online]. Lietuvos Respublikos Kultūros Ministerija, 10 November 2015 [accessed 2018-08-25]. Available from www: <https:// www.e-tar.lt/portal/lt/legalAct/ a3a3a240886611e5b7eba10a9b5a9c5f/ uHTlvzmgwm >.

Characterising online museum users: a study of the National Museums Liverpool museum website. International Journal on Digital Libraries [online]. 2018 [accessed 2018-08-26]. ISSN 1432-1300.

doi: 10.1007/s00799-018-0248-8

JONES, Michael. From catalogues to contextual networks: reconfiguring collection documentation in museums. Archives and Records [online]. 2018, vol. 39, no. 1, pp. 4-20. ISSN 2325-7962. doi: 10.1080/23257962.2017.1407750

KAPLERIS, Ignas. Information and communication technologies (ICT) transference in Lithuanian museums [online]. 2014 [accessed 2018-08-12]. Available from www: <https:// digilib.phil.muni.cz/handle/11222. digilib/131396>.

KEITH, Timothy Z. Multiple Regression and Beyond: An Introduction to Multiple Regression and Structural Equation Modeling. London: Routledge, 2015. ISBN 978-1-138-81195-9.

KING, Laura, James F. STARK a Paul COOKE. Experiencing the Digital World: The Cultural Value of Digital Engagement with Heritage. Heritage \& Society [online]. 2016, vol. 9, no. 1, pp. 76-101. ISSN 2159-032X. doi: 10.1080/2159032X.2016.1246156

Lietuvos dailes muziejaus direktoriaus ìsakymas dèl Lietuvos dailes muziejaus filialo Lietuvos muziejų informacijos, skaitmeninimo ir LIMIS centras nuostatu patvirtinimo. [online]. Lietuvos Dailès Muziejus, 7 July 2017 [accessed 2018-08-25]. Available from www: <http:// old.ldm.lt/LDM/PDF/V.1-46.pdf>.

Lietuvos Respublikos muzieju istatymas [online]. Lietuvos Respublikos Seimas, 8 June 1995 [accessed 2018-08-23]. Available from www: <https:// www.e-tar.lt/portal/lt/legalAct/ TAR.863886C4199F/RIhKcePrma>. 
MASON, David D. M. and Conal MCCARTHY. Museums and the culture of new media: an empirical model of New Zealand museum websites. Museum Management and Curatorship [online]. 2008, vol. 23, no. 1, pp. 63-80. ISSN 0964-7775. doi: 10.1080/09647770701865386

MENNA, Fabio and Erica NOCERINO.

Hybrid survey method for 3D digital recording and documentation of maritime heritage. Applied Geomatics [online]. 2014, vol. 6, no. 2, pp. 81-93. ISSN 1866-928X.

doi: 10.1007/s12518-011-0074-9

Metadata management, interoperability and Linked Data publishing support for Natural History Museums. International Journal on Digital Libraries [online]. 2014, vol. 14, no. 3, pp. 127-140. ISSN 1432-1300.

doi: 10.1007/s00799-014-0114-2

MOHNS, William H. The Digital Archive and Catalogues of the Vanuatu Cultural Centre: Overview, Collaboration and Future Directions. In Working Together in Vanuatu [online]. ANU Press, 2011 [accessed 2018-08-26], Research Histories, Collaborations, Projects and Reflections, pp. 141-150. Available from www: $<$ https://www.jstor.org/stable/ j.ctt24h3dg.23>. ISBN 978-1-921862-34-2.

MUKIENĖ, Danutè. Lithuania: The Development of the Lithuanian Integral Information System for Automated Stocktaking, Digitisation, Preservation, Search, and Access to Museum Assets. Uncommon Culture, 2010, vo. 1, no. 1, pp. 136-141. ISSN 2083-0599.

Museum Definition - ICOM. In International Council of Museums [online]. [accessed 2018-08-23]. Available from www: $<$ https://icom.museum/en/activities/ standards-guidelines/museumdefinition/>.

Muziejai ir galerijos | Lietuvos Respublikos kultūros ministerija [online]. Muziejų, Bibliotekų Ir Archyvų Skyrius [accessed 2018-08-23]. Available from www: <http://lrkm.lrv.lt/lt/veiklos-sritys/ muziejai-ir-galerijos $>$.

PARRY, Ross. Digital heritage and the rise of theory in museum computing. Museum Management and Curatorship, 2005, vol.
20, no. 4, pp. 333-348. ISSN 0964-7775. doi: 10.1016/j.musmancur.2005.06.003

Progress report of the National

Representatives Group: coordination mechanisms for digitisation policies and programmes 2002 [online]. European Commission: The Information Society Directorate-General, 2003 [accessed 2018-08-23]. Available from www:

$<$ http://www.minervaeurope. org/publications/globalreport/ globalreppdf02/appendici.pdf $>$.

LAUŽIKAS, Rimvydas and Regina VARNIENĖ-JANSSEN. Paveldas ir visuomenè: Lietuvos kultūros paveldo skaitmeninimo strateginès plètros gairès 2014-2020 metu programavimo laikotarpiui. Informacijos mokslai, 2014, vol. 69, pp. 118-143. ISSN 1392-1487.

RINDZEVIČIŪTĖ, Eglè. Post-Soviet transformation of Lithuanian state cultural policy: the meanings of democratisation. International Journal of Cultural Policy [online]. 2012, vol. 18, no. 5, pp. 563-578. ISSN 1028-6632. doi: 10.1080/10286632.2012.718916

TAYLOR, Joel and Laura Kate GIBSON. Digitisation, digital interaction and social media: embedded barriers to democratic heritage. International Journal of Heritage Studies [online]. 2017, vol. 23 , no. 5, pp. 408-420. ISSN 1352-7258.

doi: 10.1080/13527258.2016.1171245

VALTYSSON, Bjarki. Europeana. Information, Communication \& Society [online]. 2012, vol. 15, no. 2, pp. 151-170. ISSN 1369-118X. doi: 10.1080/1369118X.2011.586433

WACHOWIAK, Melvin J. and Basiliki Vicky KARAS. 3d Scanning and Replication for Museum and Cultural Heritage Applications. Journal of the American Institute for Conservation [online]. 2009, vol. 48 , no. 2 , pp. 141-158.

ISSN 0197-1360. doi: 10.1179/019713609804516992

WILCOXON, Frank. Individual Comparisons by Ranking Methods. Biometrics Bulletin [online]. 1945, vol. 1, no. 6, pp. 80-83. ISSN 0099-4987. doi: 10.2307/3001968

WU, Shao-Chun. Systems integration of heterogeneous cultural heritage information systems in museums: a case study of the National Palace Museum. International Journal on Digital Libraries [online]. 2016, vol. 17, no. 4, pp. 287304. ISSN 1432-5012, 1432-1300. doi:

10.1007/s00799-015-0154-2

Europeana Collections. In Europeana Collections [online]. [accessed 2018-08-25]. Available from www: <https:// www.europeana.eu/portal/?locale $=$ en $>$. IRIS [online]. [accessed 2018-08-23]. Available from www: <http://www. rinkinys.ldm.lt/iris/limis.htm>.

LIMIS - Muziejiniu vertybių skaitmeninimas [online]. [accessed 2018-08-25]. Available from www: <http://www. emuziejai.lt/limis/>.

Paieška - epaveldas.lt [online]. [accessed 2018-08-25]. Available from www: $<$ http://www.epaveldas.lt/home>.

Welcome - LIMIS [online]. [accessed 2018-08-23]. Available from www: <https:// www.limis.lt/en/pradinis $>$.

Welcome to Europeana Collections. In Europeana Collections [online]. [accessed 2018-08-23]. Available from www: $<$ https://www.europeana.eu/portal/en/ about.html>.

\section{AYA KIMURA}

Graduate school of Humanities and Sciences,

Ochanomizu University, Tokyo, Japan kimura.aja@gmail.com

Aya Kimura received Master's degree of Cultural Policy from the National Graduate Institute for Policy Studies (Japan) and currently pursues her Doctoral at Ochanomizu University (Japan). She was honored to receive Lithuanian State Scholarship for short-term study in 2017. In addition to museum studies, her main academic interests are digital cultural heritage, cultural policy and architecture history.

Aya Kimura ukončila magisterské studium v oboru kulturní politika v japonském Národním institutu politických studií a v současnosti je posluchačkou doktorského studia na Univerzitě Ochanomizu (Japonsko). Získala litevské státní krátkodobé stipendium pro rok 2017. K jejím hlavním badatelským zájmům patří kromě muzeologie i digitální kulturní dědictví, kulturní politika a dějiny architektury. 